\title{
SDA 法を用いた姿勢制御能の加齢変化の解析
}

\author{
Evaluation of postural control of aging change by stabilogram diffusion analysis \\ 山下和彦 ${ }^{1,2}$ (正会員), 岩上優美 ${ }^{1}$ (正会員), 今泉一哉 ${ }^{1}$ (正会員), 中島佐和子 ${ }^{2}$ (非会員), \\ 井野秀一 ${ }^{2}$ (正会員)，伊福部達 ${ }^{2}$ (正会員)，小山裕徳 ${ }^{3}$ (非会員), 川澄正史 ${ }^{3}$ (正会員) \\ Kazuhiko YAMASHITA ${ }^{1,2}$, Yumi IWAKAMI ${ }^{1}$, Kazuya IMAIZUMI ${ }^{1}$, Sawako NAKAJIMA², \\ Shuichi INO ${ }^{2}$, Toru IFUKUBE ${ }^{2}$, Hironori KOYAMA ${ }^{3}$ and Masashi KAWASUMI ${ }^{3}$
}

\begin{abstract}
Falling is one of the most common and serious problems because advancing age has been associated with muscle weakness and deterioration of postural control system. The mechanisms contributing to age-related increases in ability of postural control and falls in the elderly remain unclear. The purpose of the stabilogram diffusion analysis (SDA) method was to study change of the mechanism of postural control between young and elderly generation. Any parameters of SDA were compared with several parameters of body sway derived from recordings of the center of pressure (COP) with the aid of a static force platform. The subjects were 48 healthy young volunteers (age: 18-64 yeas, mean \pm S.D: $33.6 \pm 14.6$ years) and 41 healthy elderly volunteers (age: $65-87$ years, mean \pm S.D: $77.7 \pm 4.3$ years). They quietly stood on a static force plat form with open and closing eyes for thirty seconds. The following results were indicated. 1 . The elderly group was a significantly than the young group greater in the Diffusion constant $D_{r s}$ and the mean square critical displacement when eyes open and eyes closed. 2. On the elderly group, the correlation between SDA parameters and COP parameters was found to be greater in the closing eye condition than that in the open eye condition. 3 . The correlations between diffusion coefficient and the range of anterior-posterior was greater than the correlations between the diffusion coefficients and the range of medio-lateral. Thus, the muscle of the tibialis anterior and the planter muscles was suggested.
\end{abstract}

\section{Key Words}

Postural control, SDA method, age related change

\section{1. はじめに}

高齢者医療費や介護保険費用の高騰が社会的問題である. 高齢者の要介護度を上げる要因や寝たきりを助長する要因として 挙げられるのが転倒である゙ため, 日本各地で転倒予防のための 運動指導プログラムなどが実施されている.

\footnotetext{
2007 年 6 月 13 日受理

2007 年 7 月 21 日最終原稿受理

1 東京医療保煡大学 医療保揵学部医療情報学科, 東京都世田谷 区世田谷 3-11-3

2 東京大学 先端科学技術研究センター, 東京都目黒区駒場 4-6-1

3 東京電機大学 末来科学部 情報メディア学科, 東京都千代田区神 田錦町 2-2

1Tokyo Health Care University, Faculty of Health Care, Division of Health Care Informatics, 3-11-3 Setagaya Setagaya-ku Tokyo 2University of Tokyo, Research Center for Advanced Science and Technology, 4-6-1 Komaba Meguro-ku Tokyo

3Tokyo Denki University, School of Science and Technology For Future Life, Department of Information Systems and Multimedia Design, 2-2 Nishiki-cho Kanda chiyoda-ku Tokyo
}

転倒予防には, 下肢筋力や姿勢制御能の向上が求められ2 4), 定量的評価に基づいた転倒りスクを推定することが重要である. 特に, 姿勢制御能を定量的に解析する手法は十分に明らかでは ないため, 地方自治体などで介入プログラムを実施しても, 姿勢 制御能がどのように変化したか, 実施したプログラムがどのくらい 効果を上げたかなどは全く評価されていないのが現状である.

人間の静止立位中の姿勢制御は視覚, 聴覚, 足部からの固有 感覚情報や機械受容器からの入力, 筋制御など複雑な制御機構 を含んでいる ${ }^{5,6)}$. また足部などに変形や感染などの異常があると 転倒を誘発しやすいことが報告されており7), 姿勢制御能を評価 するためにはさまざまなアプローチが必要である.

現在行われている姿勢制御能の一部を計測, 評価する手法と して, 重心動摇計測や床反力計測が挙げられる. 一般的な姿勢 制御能の評価方法は, 静止立位中における身体の動摇量を評価 している. すなわち, 重心動摇計測による姿勢制御能の評価は, 重心の総軌跡長や面積など, 結果の積分值に着目して評価が行 
われている ${ }^{8 \sim 10)}$.これは重心の移動量が持つ振幅と移動の方向 が主に反映されるため, 時間的に変化するような動的特性には言 及していない, そのため, 重心動摇の周波数解析や 2 次元の重 心軌跡と速度に着目して解析を加える位相面解析 ${ }^{11}$ が提案され ているが，まだ姿勢制御能を適切に評価し，転倒リスクを算出でき る手法は明確にされていない12, 13).

従来の重心動摇計測では, 例えば, 重心の軌跡長や面積が大 きければ姿勢制御能が低いと評価され，実際に加齢により足圧中 心(center of pressure: COP)の重心動摇軌跡長や面積が大きくな ることなどが報告されている14 16). しかし,これらの指標は必ずしも 加龄変化や姿勢制御能を反映していないことが指摘されている ${ }^{12)}$ つまり，従来の重心動摇解析は，支持基底面の中での COP の制 御に言及しないまま, 姿勢制御能が㛟討されてきたと考えられる. そこで, COP がどのような軌跡で制御されているか, さらに, 制御 の観点から重心動摇の軌跡長がどうなると姿勢制御能が低下して いるのかを系統的に検証する試みが必要であるといえる. 以上の 理由から，高齢者の転倒リスクについて姿勢制御能の立場から評 価を加える十分な水準にはないと考えられる ${ }^{13)}$.

姿勢制御は時間的に常に変化しながら行われるため, 検証を 行うためには, 重心動摇の時間的パラメー夕にも注目する必要が ある. そこで本研究では, 重心動摇計を用いた姿勢制御能の評 価について，時間成分を考虑に入れた制御モデルを解析するた めに, Collins と DeLuca によって提案 ${ }^{17 \sim 19) さ れ た ~ s t a b i l o g r a m ~}$ diffusion analysis 法(SDA 法)を用いて検討することとした.

本論文では，若年者および高齢者を対象として重心動摇計測 を実施し, 以下の着眼点について解析を行った.

(1) 総軌跡長や面積などの従来の重心動摇の解析手法に基 ぶいて, 若年者と高齢者の各パラメータの関係を調べる.

(2) 従来のパラメータとSDA 法によって得られるパラメータが加 齢によりどのような変化をたどるかを調べる.

(3) 上記 2 項目より，加齡による姿勢制御の手法がどのように 変化したかを推定する.

以上を解析することにより，高齢者の姿勢制御のストラテジ の変化について言及することとする.

\section{2. 対象者}

対象者は若年者群 48 名 (平均年齢 $33.6 \pm 14.6$ 歳, 18 64 歳)， 高齢者群 41 名 (平均年齢 $77.7 \pm 4.3$ 歳, 65〜87 歳) である. すべ ての対象者は自立歩行可能で, 心疾患, 脳血管疾患等の既往歴 がないことを確認した. 对象者には, 実験の主旨等を事前に説明 し、インフォームドコンセントが得られた上で実験を行った.

\section{3. 英酫方法}

\section{1 实酫条件}

重心動摇計測は, Midi Capteures 社製の Twin99 を用いた. サ ンプリング周波数は $20 \mathrm{~Hz}$, 計測時間は 30 秒とした. 重心動摇計 の上には，素足で足をほほ平行にそろえる形で乗るよう指示した。
実験に際しては, 開眼および閉眼両足立ちの静止立位での計測 をそれぞれ1回ずつ行い，計測中はできるだけ動かないよう指示 し, 開眼時は正面を注視するよう指示した。

\section{2 SDA 法による姿勢制御能の解析}

COP軌跡は非定常であり, ランダム性を多く含んでいると考えら れる ${ }^{20}$. そこで本研究では, COP 軌跡の結果を確率論的立場から ブラウン運動などで用いられるランダムウォーク理論に基づいて構 築された SDA 法により解析するものである ${ }^{17 ~ 19) . ~}$

$\mathrm{COP}$ 軌跡は，左右方向の時系列に座標データ $\mathrm{x}_{\mathrm{i}}$ および前後

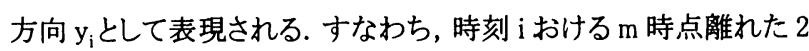
点間の距離 $\Delta \mathrm{r}_{\mathrm{m}(\mathrm{i})}$ を式 1 のように定義した. さらに, 式 2 により時間 間隔 $\Delta \mathrm{t}\left(=\mathrm{Tm}, \mathrm{T}\right.$ はサンプリング間隔)の 2 点間の平均距離 $(\Delta \mathrm{r})_{\Delta t}$ を求めた。

ここで, $\mathrm{N}$ は全データ数, $\mathrm{m}$ は時間間隔 $\Delta \mathrm{t}$ に相当するデータの 間隔を意味する.したがって, 式 2 は $\Delta \mathrm{r}_{\mathrm{m}(\mathrm{l})}$ から $\Delta \mathrm{r}_{\mathrm{m}(\mathrm{N}-\mathrm{m})}$ まで $\mathrm{m}$ デ 一夕間隔で移動平均した結果が $\left(\Delta r_{\Delta t}\right)^{2}$ として得られることとなる.

$$
\begin{array}{cc}
\left(\Delta \mathrm{r}_{m(i)}\right)^{2}=\left(\mathrm{x}_{i}-\mathrm{x}_{(i+m)}\right)^{2}+\left(\mathrm{y}_{i}-\mathrm{y}_{(i+m)}\right)^{2} & \text { 式 1 } \\
\left(\Delta r_{\Delta t}\right)^{2}=\frac{\sum_{i=1}^{N-m}\left(\Delta r_{m(i)}\right)^{2}}{(N-m)} & \text { 式 2 }
\end{array}
$$

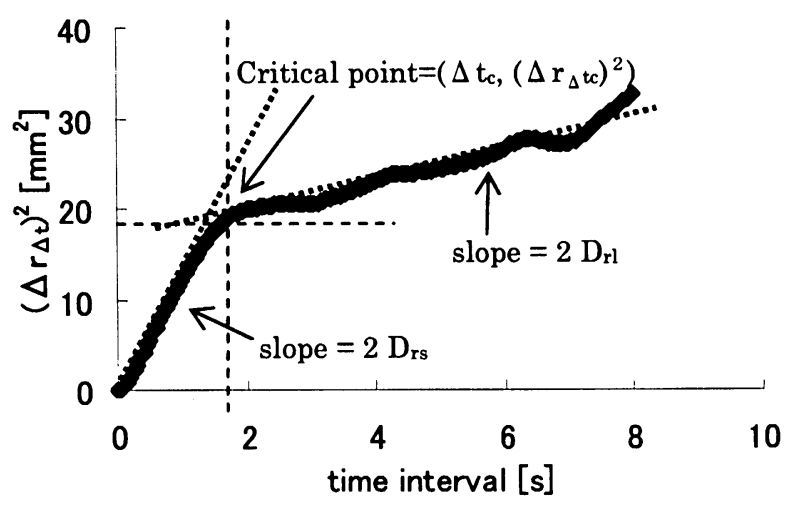

Fig.1 Example of COP analysis using SDA

式 2 より求められる SDA 法の結果の一例を Fig.1 に示す. Fig.1 より, 横軸は $\Delta \mathrm{t}$, すなわち 2 つのペアの時間間隔(time interval) とし, 縋軸は式 2 より算出された $\left(\Delta \mathrm{r}_{\Delta \mathrm{t}}\right)^{2}$ とした.この結果をプロット すると Fig.1 のように 2 つの領域に分けられることがわかる. この 2 つの領域に対し, 最小二乗法を用いて, それぞれに直線を当て はめ, その交点を境界点と定義した.この境界点までの時間を critical time interval (CTI), 境界点までの距離の 2 乗 $\left(\Delta \mathrm{r}_{\Delta \mathrm{cc}}\right)^{2}$ を mean square critical displacement (MSCD) と定義した.

Collins らは, 境界点までの領域を短期間領域 (short-term region)と定義し, 開ループシステム (open loop system)による制 御がなされ,これを越える領域を長期間領域 (long-term region)と し, 閉ループシステム(closed loop system)による制御がなされて 
いると報告している ${ }^{17)}$.ここでいう開ループシステムとは, 静止立 位時の足底の安定中心点からCOPが遠ざかる方向の動きに相当 し, その移動を閉ループシステムが制御, すなわち, 安定中心点 に向けて COP を戻そうとするフィードバック制御を行うことに相当 する.

この考えに基づくと, CTI は開ループシステムによって決定され る安定性維持のための時間間隔を示し, short-term regionに当て はめた直線の傾きが大きいほど COP の確率論的活動が大きいこ とを示唆していると考えられる ${ }^{12,19)}$.

本研究では, これらの考え方を取り入れ, short-term region, long-term regionに当てはめられた直線を拡散係数 D とし解析を 進めた。拡散係数 D は図中の傾きから算出し, short-term region に当てはまる傾きを $\mathrm{D}_{\mathrm{rs}}$ (diffusion coefficients of short term region on plane of support: 支持平面上における短期間領域の拡散係 数), long-term region の傾きを $\mathrm{D}_{\mathrm{rl}}$ (diffusion coefficients of long term region on plane of support: 支持平面上における長期間領域 の拡散係数)と表現した. 添え字の $\mathrm{r}$ は左右方向の座標を表す $\mathrm{x}$ と前後方向の座標を表す $\mathrm{y}$ の平方平均から求められる距離 $\mathrm{r}$ を意 味している。

本研究では, 特に, 開ループシステムによる COP の確率論的 活動の強さと姿勢制御へ与える影響を調べるために， $D_{\mathrm{rs}}$, MSCD, CTI 着目して解析を加えた.

\section{4. 解析方法}

本研究では, SDA 法によって得られた結果と従来用いられてい る重心動摇計測のパラメータの比較を行った. そこで, 従来用い られている重心動摇計測のパラメータとして, 総軌跡長(total path length, 以下 length と表記), 面積(area), 左右方向の平均速度 (ML velocity)および最大移動距離(ML range), 前後方向の平均 速度 (AP velocity) および最大距離 (AP range) とし, SDA 法から得 られるパラメータとして $D_{\mathrm{rs}}$, 開ループシステムと閉ループシステム の境界点 (critical point) までの時間間隔 CTI と距離のパラメータ MSCD とした.

高龄者群と若年者群の結果の検定は関連のない $\mathrm{t}$ 検定を用い, 従来の重心動摇の各パラメータ, SDA 法から導かれる $\mathrm{D}_{\mathrm{rs}}, \mathrm{MSCD}$, CTI の相関はピアソンの積率相関係数から求めた.

\section{5. 实験結果}

Fig.2，3，4にはSDA 法によって得られる $\mathrm{D}_{\mathrm{rs}}, \mathrm{CTI}, \mathrm{MSCD}$ を年 齢別に表示した. 年齢は 18-30 歳の青年群, 31-64 歳の中年群, 65-75 歳の前期高龄者群, 75 歳以上の後期高齢者群とした. SDA 法から得られるパラメータの加齢変化を確認するために分類 を行ったので, 従来の重心動摇のパラメータとの比較の際には, 65 歳未满の若年者群, 65 歳以上の高龄者群と分けることとした.

Fig. 2 より, $D_{\mathrm{rs}}$ は 65 歳未満では, 視覚入力の有無にかかわらず, 1.3 以下を保っているのに対し, 高龄者群では, 30 歳以下の青年 群に比べ, 前期高齢者群で開眼時に 1.9 倍, 閉眼時で 2.8 倍, 後

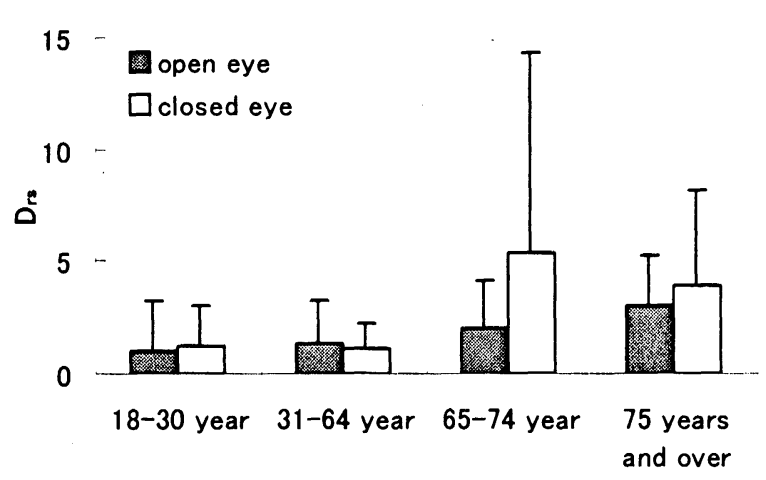

Fig.2 Aging change of $D_{r s}$ with or without visual input

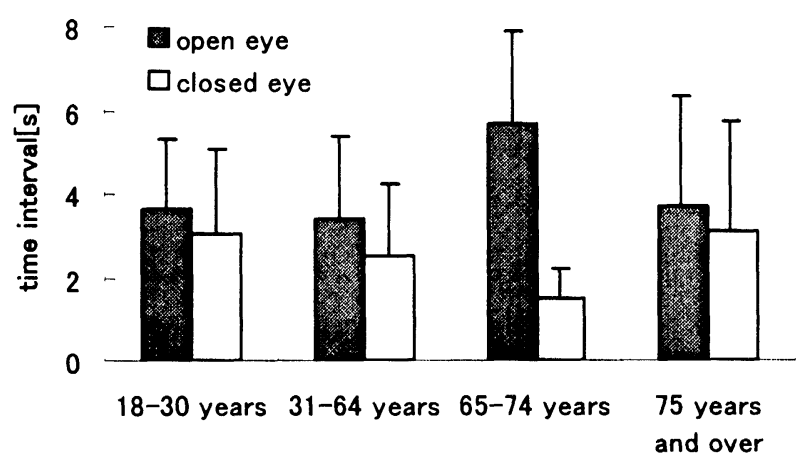

Fig.3 Aging change of CTI with or without visual input

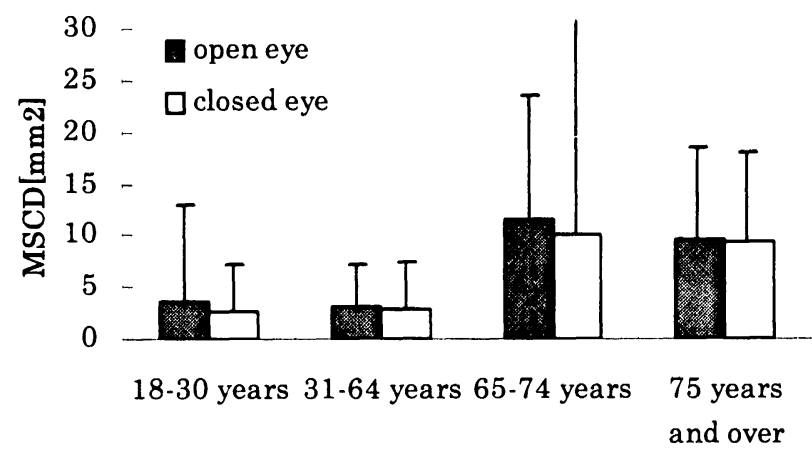

Fig.4 Aging change of MSCD with or without visual input

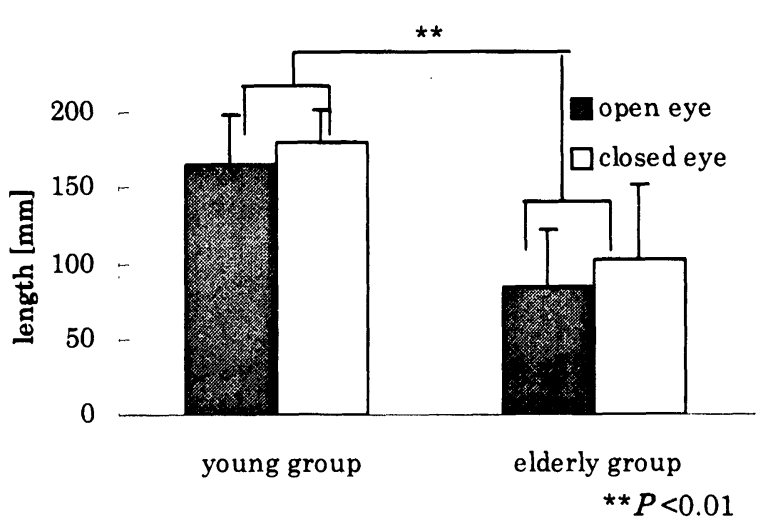

Fig.5 Aging change of total path length with or without visual input 
Table $1 \mathrm{D}_{\mathrm{rs}}$ between young group and elderly group

\begin{tabular}{c|cc|cc|cc|cc|} 
& \multicolumn{2}{|c|}{ length } & \multicolumn{2}{c|}{ area } & \multicolumn{2}{c|}{ ML velocity } & \multicolumn{2}{c|}{ AP velocity } \\
& open eye & closed eye & open eye & closed eye & open eye & closed eye & open eye & closed eye \\
\hline young group & $0.46^{\star \star}$ & $0.31^{\#}$ & $0.93^{\star *}$ & $0.93^{\star *}$ & $0.43^{*}$ & $0.93^{\star *}$ & $0.41^{\star}$ & $0.34^{*}$ \\
elderly group & 0.19 & $0.85^{\star *}$ & $0.92^{\star *}$ & $0.79^{* *}$ & 0.07 & $0.84^{\star \star}$ & $0.28 \#$ & $0.79^{\star \star}$
\end{tabular}

\begin{tabular}{|c|c|c|c|c|c|c|c|}
\hline & \multicolumn{2}{|c|}{ ML maximum renge } & \multicolumn{2}{|c|}{ AP maximum renge } & \multicolumn{2}{|c|}{ MSCD } & \multirow{2}{*}{${ }^{* \star} P<0.001$} \\
\hline & open eye & closed eye & open eye & closed eye & open eye & closed eye & \\
\hline & $0.8^{\star \star}$ & $0.71^{\star \star}$ & 0.87 ** & $0.87 * \star$ & $0.88^{\star \star}$ & $0.84^{\star \star}$ & \\
\hline elderly group & $0.47^{*}$ & $0.8 * *$ & 0.74 ** & $0.62^{\star *}$ & $0.46^{*}$ & $0.71^{\star}$ & $><0.0$ \\
\hline
\end{tabular}

Table 2 MSCD between young group and elderly group

\begin{tabular}{c|cc|cc|cc|cc|} 
& \multicolumn{2}{|c|}{ length } & \multicolumn{2}{c|}{ area } & \multicolumn{2}{c|}{ ML velocity } & \multicolumn{2}{c|}{ AP velocity } \\
& open eye & closed eye & open eye & closed eye & open eye & closed eye & open eye & closed eye \\
\hline young group & $0.46^{\star \star}$ & 0.23 & $0.93^{\star \star}$ & $0.83^{\star \star}$ & $0.42^{\star}$ & 0.2 & $0.47^{\star \star}$ & 0.23 \\
elderly group & 0.05 & $0.55^{\star \star}$ & $0.6^{\star \star}$ & $0.69^{\star \star}$ & -0.06 & $0.62^{\star \star}$ & 0.14 & $0.44^{\star}$
\end{tabular}

\begin{tabular}{|c|c|c|c|c|c|}
\hline & \multicolumn{2}{|c|}{ ML maximum renge } & \multicolumn{2}{|c|}{ AP maximum renge } & \multirow[b]{2}{*}{${ }^{\star \star} P<0.001$} \\
\hline & open eye & closed eye & open eye & closed eye & \\
\hline & $0.77^{\star \star}$ & $0.55^{\star \star}$ & $0.81 * \star$ & $0.86^{\star \star}$ & ${ }^{*} P<0.01$ \\
\hline elderly group & 0.06 & $0.86^{\star \star}$ & $0.78^{* \star}$ & $0.52^{\star \star}$ & \\
\hline
\end{tabular}

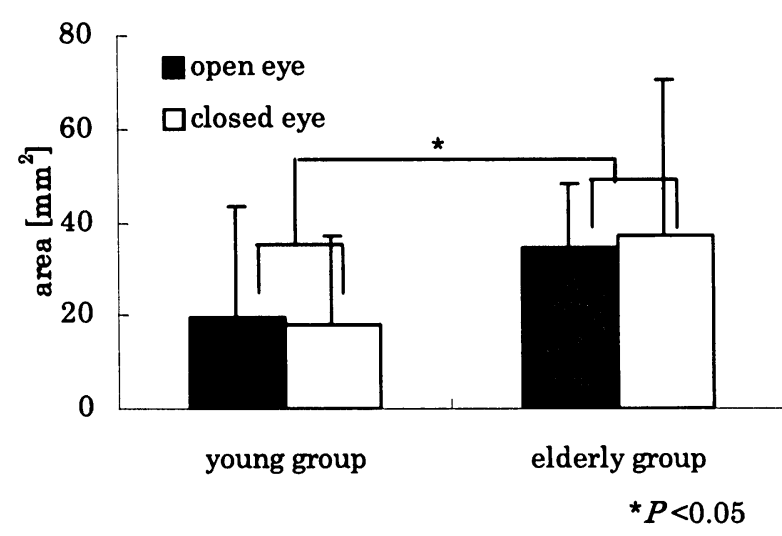

Fig.6 Aging change of area with or without visual input

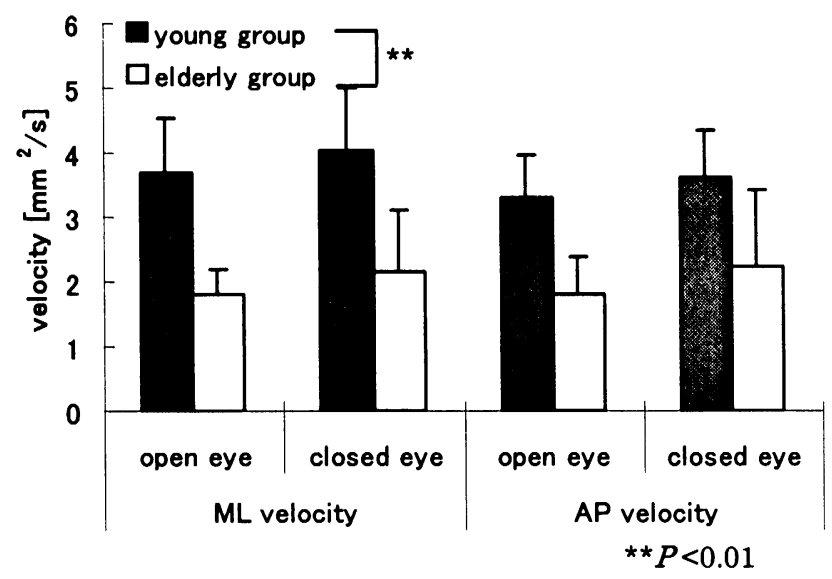

Fig.7 Aging change of average displacement velocity with or without visual input

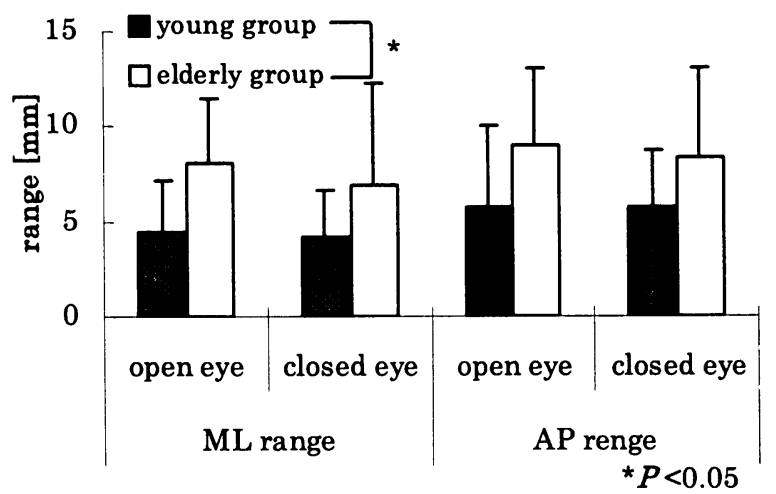

Fig.8 Aging change of displacement range with or without visual input

期高龄者群で開眼時に 4.4 倍, 閉眼時で 3.2 倍大きくなった.つ まり, 加龄により拡散倸数 $\mathrm{D}_{\mathrm{rs}}$ の傾きが大きくなり, 開ループの確率 論的活動度が青年・中年群に比べて大きいことがわかった.

Fig.3 より, CTI は前期高齢者群で開眼と閉眼の差が大きいこと と, 開眼時に比べて閉眼時の方が CTI が小さい傾向にあることが 読み取れるが, それ以外は加噛による CTI への影響は確認され なかった.

Fig.4より, MSCD は 64 歳以下の青年, 中年群では開眼時で 3.6 $\mathrm{mm}^{2}$ 以下, 閉眼時で $2.8 \mathrm{~mm}^{2}$ 以下であるのに対し, 高龄者群では, 青年群に比べて, 前期高齢者群で開眼時に 3.2 倍, 閉眼時に 2.7 倍, 後期高龄者群で開眼時に 3.7 倍, 閉眼時で 3.4 倍大きいこと がわかった.

Fig.5 より, 若年者群と高龄者群の総軌跡長を比較すると, 若年 者群に比べて高齢者群の総軌跡長の方が, 開眼時で $49 \%$, 閉眼 時で 43\%小さいことがわかった. Table 1 より, $\mathrm{D}_{\mathrm{rs}}$ と総軌跡長の関 係は, 若年者群の開眼で相関係数が 0.46 , 閉眼で 0.31 , 高齢者 
群の開眼は相関が認められず, 閉眼で 0.85 であった. Table 2 より, MSCD と総軌跡長の関係は, 若年者群の開眼で 0.46, 高齢者群 の閉眼で 0.55 であった. $\mathrm{D}_{\mathrm{rs}}, \mathrm{MSCD}$ と総軌跡長の間には, 同じよ うな相関の傾向がうかがえた.

Fig.6より, 若年者群と高龄者群の面積を比較すると, 若年者群 に比べて高齢者群の面積は, 開眼で 1.8 倍, 閉眼で 2.1 倍大きい ことがわかった. Table 1 より, $\mathrm{D}_{\mathrm{rs}}$ と面積の関係は, 若年者群の相 関係数は開眼, 閉眼ともに 0.93 , 高齢者群の開眼は 0.92 , 閉眼は 0.79 といずれも高い相関が認められた. Table 2 より, MSCD と面 積の関係は, $\mathrm{D}_{\mathrm{rs}}$ と同様に高い相関が認められ, 若年者群の開眼 で 0.93 , 閉眼で 0.83 , 高齢者群の開眼で 0.6 , 閉眼で 0.69 であっ た.

Fig.7 より, 左右方向 (ML)の COP の移動速度を比較すると, 若 年者群に比べて, 高齢者群の左右方向の移動速度は, 開眼で $52 \%$, 閉眼で 47\%小さいことがわかった. Table 1 より, $\mathrm{D}_{\mathrm{rs}}$ と左右方 向の移動速度の関係は, 若年者群の開眼で 0.43 , 閉眼で 0.93 , 高齢者群の開眼では相関が認められず, 閉眼で 0.84 であった. 開眼時よりも閉眼時の方が $D_{\mathrm{rs}}$ と左右方向の COP の移動速度に 高い相関が認められた. Table 2 より, MSCD と左右方向の移動速 度の関倸は, $\mathrm{D}_{\mathrm{rs}}$ 之同様の傾向が見られ, 若年者の開眼で 0.42 , 高齢者の閉眼で 0.62 の相関が認められた.

Fig.7 より前後方向 (AP)の COP の移動速度を比較すると, 若年 者群に比べて, 高齢者群の前後方向の移動速度は, 開眼で $45 \%$, 閉眼で $48 \%$ 小さいことがわかった. Table 1より, $\mathrm{D}_{\mathrm{rs}}$ と前後方向の移 動速度の関係は, 若年者群の開眼で 0.41 , 閉眼で 0.34 , 高齢者 群の開眼で 0.28 , 閉眼で 0.79 であった. Table 2 より, MSCD と前 後方向の移動速度の関係は, 若年者の開眼で 0.47 , 高齢者の閉 眼で 0.44 の相関が認められた.

Fig.8 より, 左右方向の COP の最大移動距離を比較すると, 若 年者群に比べて, 高齢者群の左右方向の最大移動距離は, 開眼 で 1.8 倍, 閉眼で 1.6 倍大きいことがわかった. Table 1 より, $\mathrm{D}_{\mathrm{rs}}$ と 左右方向の最大移動距離の関係は, 若年者群の開眼で 0.80 , 閉 眼で 0.71 , 高龄者群の開眼で 0.47 , 閉眼で 0.80 であった. 開眼 時よりも閉眼時の方が $\mathrm{D}_{\mathrm{rs}}$ と左右方向の COP の最大移動距離に 高い相関が認められた. Table 2 より, MSCD と左右方向の最大移 動距離の関係は, 若年者群の開眼で 0.77 , 閉眼で 0.55 , 高齢者 群の閉眼で 0.86 と高い相関が認められた.

Fig.8 より, 前後方向の COP の最大移動距離を比較すると, 若 年者群に比べて, 高齢者群の前後方向の最大移動距離は, 開眼 で 1.6 倍, 閉眼で 1.5 倍大きいことがわかった. Table 1 より, $\mathrm{D}_{\mathrm{rs}}$ と 前後方向の最大移動距離の関係は, 若年者群の開眼で 0.87 , 閉 眼で 0.87 , 高齢者群の開眼で 0.74 , 閉眼で 0.62 であった. 開眼 および閉眼ともに $\mathrm{D}_{\mathrm{rs}}$ と前後方向の COP の最大移動距離に高い 相関が認められた. Table 2 より, MSCD と前後方向の最大移動距 離の関係は, 若年者群の開眼で 0.81 , 閉眼で 0.86 , 高齢者群の 開眼で 0.78 , 閉眼で 0.52 と高い相関が認められた. 左右方向の 移動距離と比べて, 高齢者群の閉眼時を除き, 前後方向の方が
高い相関が認められた.

Table 1 より, $\mathrm{D}_{\mathrm{rs}}$ と MSCD の間には, 若年者で開閉眼ともに約 0.85 , 高齢者群の開眼で 0.46 , 閉眼で 0.71 と相関が認められた. $\mathrm{D}_{\mathrm{rs}}$ とMSCD 間に相関が認められたことから, Table 1の $\mathrm{D}_{\mathrm{rs}}$ と Table 2 の MSCD と総軌跡長などの各パラメータにおいて類似した相関 係数の結果が得られたといえる.

また, 結果は記載しないが, 時間のパラメータである CTI は $\mathrm{D}_{\mathrm{rs}}$, MSCD とは相関が認められず, 重心動摇の各パラメータとも有意 な相関は見出せなかった.

Table 3 に若年者群と高齢者群の間で得られた結果をまとめて 記載した. $\mathrm{D}_{\mathrm{rs}}$ とMSCD は若年者群よりも高齢者群の方が大きいが, CTI に両群間に差がないことがわかった. 総軌跡長と前後左右方 向の重心の移動速度は若年者が高齢者群よりも大きいのに対し, 面積と前後左右の移動範囲は若年者群の方が高齢者群よりも大 きいことが本結果よりわかった。

Table 3 Result between young group and elderly group on parameters

\begin{tabular}{cc}
\hline $\mathrm{D}_{\mathrm{rs}}$ & : young group < elderly group \\
$\mathrm{MSCD}$ & : young group < elderly group \\
$\mathrm{CTI}$ & : young group = elderly group \\
total path length: young group $>$ elderly group \\
area $\quad$ : young group < elderly group \\
$\mathrm{ML} \cdot \mathrm{AP}$ velocity: young group $>$ elderly group \\
$\mathrm{ML} \cdot$ AP range :young group < elderly group \\
\hline
\end{tabular}

\section{6. 考察}

\subsection{SDA 法のパラメータによる姿勢制御能の解析}

本研究では, 高齢者と若年者の姿勢制御能の制御システムの 変化, 従来の姿勢制御能の評価パラメータとSDA 法から得られる パラメータの関係, その加齢変化について考察するために開眼, 閉眼両足立ち時の重心動摇計測を行った.

結果より, 開ループ制御の確率論的活動度を意味する $\mathrm{D}_{\mathrm{rs}}$ は若 年者群よりも高齢者群の方が大きいことがわかり, 特に高齢者群 の場合，閉眼により $\mathrm{D}_{\mathrm{rs}}$ は大きく表れることがわかった.また， MSCD についても若年者群より高龄者群の方が大きく表れ, $\mathrm{D}_{\mathrm{rs}}$ と 同様の結果が認められ， $\mathrm{D}_{\mathrm{rs}}$ と MSCD の相関も認められた.つまり， 開ループ制御の確率論的活動度が大きいことは, 境界点までの 距離を延長させ，支持基底面が大きく使われることが推測された.

一方, Fig.4 より, 境界点までの時間のパラメータである CTI に 加齢変化は認められず, COP の各パラメータ, $\mathrm{D}_{\mathrm{rs}}, \mathrm{MSCD}$ との相 関も認められなかった(結果省略).つまり, 姿勢制御のメカニズム の中で, 鍵となる評価項目は, 時間による制御ではなく, COP の 位置情報を参照しながら, 姿勢制御が行われていることが推察さ れた.

COP の位置情報を取得するために使われる生体情報は, 視覚, 感覚器官で運動感覚をつかさどる三半規管や耳石器, 足裏の固 有感覚情報や機械受容器などが該当する. Fig.2 の $\mathrm{D}_{\mathrm{rs}}$ は, 視覚 
を遮断する閉眼時において, 65 歳以上の高齢者群は開眼時の 1.3 倍大きくなった. 視覚は生体情報の 8 割を占めるといわれ, 視 覚情報を遮断することは, 閉ループシステムによって起こる COP の安定中心点から遠方への移動の情報を視覚情報によって補正 することが不十分となり, フィードバックループによる制御の遅れを 生じると考える. 以上の理由から, 姿勢制御の開ループ部分の確 率論的活動度が大きくなることが推察された.

一方で MSCD は開眼よりも閉眼の方が同等か, むしろ小さくな る傾向がうかがえる.これは，姿勢制御を行える支持基底面の大 きさに関係していると考えられる. 安定に COP を制御できる支持 基底面の実効值は, 下肢筇力や体の骨格の関係からほぼ決まっ ていると推測できる.したがって, 開眼, 閉眼にかかわらず, COP を制御できる最大値はそれほど変化しないことを意味すると考えら れる. その結果, Fig.6の開閉眼時の面積, Fig.8 の左右方向の最 大移動距離, 前後方向の最大移動距離の結果からも, 開眼, 閉 眼時で同等か, むしろ小さくなる傾向にあると考える.

\section{2 加秢による重心動摇のパラメータの変化}

Fig.5 より, 若年者群に比べて高齢者群の総軌跡長は約 4 割小 さくなることがわかった. また, Fig.6 より面積は高龄者群の方が約 2 倍大きくなることがわかった. さらに, Fig.8 からは, 前後左右の COP の最大移動距離が若年者群に比べて 1.5 1.8 倍扡大して いる結果が得られた。

これは加齢により COP の制御点が, 足圧中心の最も安定な重 心点から遠くまで離れて行われていることを表している. COPの距 離が安定点から離れるということは，モーメントアームが長くなるこ とを意味するため, その制御のためには, 制御を担当する主導筋 に大きな負荷がかかると考えられる.したがって，COP を制御する ために, 加えられる力が大きくなることでエネルギーが必要となる. ここで使える力の最大值が一定だとすると, 遠くのものを制御する ためのエネルギー密度は小さくなると考えられる.したがって, Fig.7 の前後左右方向の移動速度に表されるように, 高齢者群の 方が若年者群よりも, 約 40〜 50\%小さくなると考えられ，総軌跡長 も小さくなると考えられる.

先行研究では, 加齢により総軌跡長が長くなるという報告 ${ }^{15.16) や ~}$ 平均移動速度は加齢変化を表すが, 総軌跡長や面積は変化しな

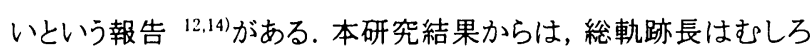
加齢により減少し, COP の制御のエネルギーという観点から, 面 䅡, および, 前後左右の COP の最大移動距離は拡大し, 前後左 右の平均移動速度は減少することが示唆された。

さらに SDA 法のパラメータから $\mathrm{D}_{\mathrm{rs}}$ と MSCD が拡大する傾向に あることがわかった. すなわち, 足底部における COP の支持基底 面の実効值が扡大するとともに, 制御の確率論的要素が大きくな ることを表しており, 本結果で表される総軌跡長の減少, 面積およ び前後左右の最大移動範囲の扡大は妥当であると考えられる.

\subsection{SDA法のパラメータと従来の重心的摇計測によるパラメータ}

\section{の比較}

搪散係数 $\mathrm{D}_{\mathrm{rs}}$ は面積, 左右方向(ML)の最大移動距離, 前後方 向(AP)の最大移動距離に高い相関が認められた. Table 2 より, MSCD は面積, 前後方向(AP)の最大移動距離に高い相関が認め られた. 特に, $D_{\mathrm{rs}}$ と最大移動距離の関係は左右方向よりも前後方 向で高い相関が認められた.これは MSCD についてもほぼ同様 の結果であった。

姿勢の制御方法を解剖学的に考えると, 前後方向の動きは前 頸骨筋と足底腱膜, 足関節周辺の筋や前足部の機能が関与 ${ }^{21)} し$ ており, 左右方向の動きは, 股関節周辺の筋活動が関与している 21)と考えられる. さらに姿勢制御は足関節一股関節戦略の手法か ら, 静止立位のような小さい範囲の制御は足関節が担当し, 足関 節で対応できないような大きな動摇について股関節が担当するこ とが報告されている゙22.

本研究では外乱等を加えることはしていないため, 自発的動摇 のみに着目している.したがって本研究からは主に足関節戦略に よる制御がなされていると予測される. Fig.8 より, 左右方向の最大 移動距離の平均値と標準偏差は, 若年者群の開眼で $4.4 \pm 0.5$ $\mathrm{mm}$, 閉眼で $4.2 \pm 0.6 \mathrm{~mm}$, 高齢者群の開眼で $8.1 \pm 1.8 \mathrm{~mm}$, 閉眼 で $6.8 \pm 1.6 \mathrm{~mm}$ であった. 前後方向の最大移動距離の平均值は, 若年者群の開眼で $5.7 \pm 0.6 \mathrm{~mm}$, 閉眼で $5.7 \pm 0.7 \mathrm{~mm}$, 高齢者群 の開眼で $9.0 \pm 1.6 \mathrm{~mm}$, 閉眼で $8.3 \pm 1.5 \mathrm{~mm}$ であった. すなわち, 若年者群, 高齢者群ともに開閉眼状態において前後方向の最大 移動距離の方が左右方向よりも大きいことがわかった. $\mathrm{D}_{\mathrm{rs}}$ も左右 方向よりも前後方向で高い相関が認められていることから, 姿勢の 制御には左右方向よりも前後方向に積極的に行われていると推 測できる.

この理由として，上述したように動摇を制御するための解剖学 的見地から, 前足部である足指が前後方向の姿勢制御のための トルクを発生させて自発的に発生する動摇を制御しているため, 左右方向よりも前後方向の方が制御しやすいことが考えられる.

すなわち, 本研究から得られた拡散係数 $\mathrm{D}_{\mathrm{rs}}$ の結果は, 足関節 のトルクを発揮する筋, 例えば, 前頸骨筋, 足底腱膜, 足関節周り の筋により動摇を積極的に制御した結果が反映されていると考え る.つまり横方向の動摇に対しては股関節周辺で行うことになるの で, 前後方向よりは確率的な制御になっており, 割合として低い相 関となったと考えた.

これまでの重心動摇計を用いた姿勢制御能の評価では, 総軌 跡長, 面積, 前後左右方向の最大移動距離を用いることが多かっ た. 本研究結果の総軌跡長のばらつきを見ると, 開閉眼ともに面 積の結果よりも大きくなるとともに, $\mathrm{D}_{\mathrm{rs}}$ との相関も低いことがわかる. また, 前後左右の速度についても同様の結果であった. また, 左 右方向の最大移動距離よりも前後方向の方が相関が高く, 加齢 による姿勢制御能の低下の割合を多く反映すると考えられること がわかった. 前後方向は解剖学的見地からも姿勢制御能自体を 反映させ,それはDrs およびMSCD との相関関倸からも推測でき 
た. 以上のように, 加齢に伴う姿勢制御能のストラテジの変化が解 析された.

\section{7. 結論}

本研究では, 若年者と高齢者の姿勢制御モデルの違いを解析 するために SDA 法と, 従来から行われている COP 解析のパラメ 一タとの比較を行った.

その結果, SDA 法による $\mathrm{D}_{\mathrm{rs}}$ と MSCD は加齢により大きくなるこ とがわかった. そして, $\mathrm{D}_{\mathrm{rs}}$ および MSCD は従来のパラメータである 面積, 前後左右の最大移動距離との間に高い相関に認められる ことがわかった。

総軌跡長や面積が大きくなる要因の 1 つとして, 生体中の開ル ープシステムの確率論的活動度が大きくなることが考えられる.さ らに, $\mathrm{D}_{\mathrm{rs}}$ およびMSCD は COPの前後方向の移動範囲と高く相関 があることがわかり, その理由として, 前頸骨筋や足底腱膜, 前足 部の機能などを使った制御の影響が推察された.一方時間のパ ラメータである CTI は COP の各パラメータとの相関が認められな かった.

本研究結果より, SDA 法により導出されるパラメータ, 特に $\mathrm{D}_{\mathrm{rs}}$ およびMSCD の意義が実験的および解剖学的観点から推定でき， 転倒リスク推定に利用できる可能性が示唆された. さらに, 従来か ら用いられているパラメータの要素を高い相関係数から含有して いることが認められ，このことは SDA 法の確率論的解析手法が姿 勢制御能の評価に有効であることを示していると考えられる.

謝辞: 本研究の一部は厚生労働省科学研究費 長寿科学総合研 究事業 (H18-長寿-若手-002), 文部科学省科学研究費若手(B) (課題番号 18700479), 文部科学省科学研究費補助金(C)（課 題番号 17500481), 文部科学省科学研究費補助金(C)(課題場号 18500441), 文部科学省科学研究費補助金 (B) (課題番号 18300191), 平成 19 年度（財）明治安田厚生事業団, 平成 18 年度笹川科学研究助成, 平成 18 年度石本記念デサントスポー ツ科学振興財団の研究助成にて行われた.

\section{引用文献 :}

1）厚生労働省, 国民生活基礎調査 '(2004)

2) Province MA, Hadley EC, Hornbrook MC, Lipsitz LA, Miller JP, Mulrow CD, Ory MG, Sattin RW, Tinetti ME, Wolf SL, The effects of exercise on falls in elderly patients a preplanned meta-analysis of the FICSIT trials. JAMA 1995; 273: pp.1341-1347 3）木村みさか, 奥野直, 岡山寧子, 田中靖人, 高齢者の立位姿 勢保持能に関する一考察. 体育科学 1998;26:pp.103-114 4）鈴木隆雄, 杉浦美穂, 古名丈人, 西澤哲, 吉田英世, 石崎達 郎, 金憲経, 湯川晴美, 柴田博, 地域高齢者の転倒発生に関連 する身体的要因分析的研究 -5 年間の追跡研究から. 日医老誌 $1999 ; 36:$ pp.472-478

5) Magnusson M, Enbom H, Johansson R, Wiklund J, Significance of pressor input from the human feet in lateral postural control. Acta Otolaryngol. 1990; 110: pp.321-327

6) Bisdorff AR, Bronstein AM, Wolsley C, Gresty MA, Davies A, Young $A, E M G$ responses to free fall in elderly subjects and akinetic rigid patients. J Neurol Neurosug Psychiatry 1999; 66: pp.447-455

7）山下和彦, 野本洋平, 梅沢淳, 宮川晴妃, 川澄正史, 小山裕 徳, 斎藤正男, 高齢者の足部・足爪異常による転倒への影響. 電 学誌 C 2004 ; 124 :pp.2057-2063

8) Lord SR, Clark RD, Webster IW, Postural stability and associated physiological factors in a population of aged persons, J Gerontol. 1991; 46: pp.69-76

9) Black FO, Wall C, Rockette HE, Kitch R, Normal subject postural sway during he Romberg test. AM J Otolanrynol 1982; 3: pp.309-318

10) Goldie PA, Bach TM, Evans OM, Force platform measures for evaluating postural control: reliability and validity. Arch Phys Med Rehbil. 1989; 70: pp.510-517

11) Riley PO, Benda BJ, Gill-Body KM, Krebs DE, Phase plane analysis of stability in quiet standing. J Rehabil Res Dev. 1995; 32 : pp.227-235

12) Raymakers JA, Samson MM, Verhaar HJJ, The assessment of body sway and the choice of the stability parameter(s). Gait and Posture 2005; 21: pp.48-58

13) Collins JJ, DeLuca CJ. Burrows A, Lipsitz LA, Age- related changes in open-loop and closed-loop postural control mechanisms. Exp Brain Res. 1995; 104: pp.480-492

14) Laughton CA, Slavin M, Katdare K, Nolan L, Bean JF, Kerrigan DC, Phillips E, Lipsitz LA, Collins JJ, Aging, muscle activity, and balance control: physiologic changes associated with balance impairment. Gait and posture 2003; 18: pp.101-108 15) Hasselkus BR, Shambes GM, Aging and postural sway in women. J. Gerontol. 1975; 30: pp.661-667

16) Murry MP, Seireg AA, Sepic BB, Normal postural stability and steadiness: quantitative assessment. J.Bone Joint Surg. 1975; 57:pp.510-516

17) Collins JJ, DeLuca CJ, Open-loop and close-loop control of posture: A random-walk analysis of center of pressure trajectoryes. Exp Bain Res. 1992; 95: pp.308-318

18) Collins JJ, DelLuca CJ, Random walking during quiet standing. Phys Rev Lett. 1994; 73: pp.764-767

19) Collins JJ, DeLuca CJ, Upright, correlated random walks: a statistical-biomechanics approach to the human postural control system. Chaos 1995; 5: pp.57-63

20) Duarte M., Zatsiorsky M, On the fractal properties of natural human standing: Neurosci. 2000; 283: pp.173-176

21) Winter DA, Patla AE, Prince F, Ishac M, Giolo-porczak k, Stiffness control of balance in quiet standing. J Neuro- physiol. 1998; 80: pp.1211-1221

22) Runge $C F$, Shupert CL, Horak FB, Zajac FE, Ankle and hip postural strategies defined by joint torques. Gait posture 1999; 10: pp.161-170 